\title{
Experimental study on particulate control of turbo gasoline engine
}

\author{
Shicheng Li ${ }^{*}$, Kongwu Chen, Yongsheng Long, Hao Peng, Jingbo Wang, and Tianhong \\ Kang \\ Dongfeng Motor Company Technology Center, 430058, China
}

Keywords: port fuel injection engine, VVT, injector, fuel control, particulate emissions.

\begin{abstract}
This study takes light-passenger vehicles with $1.5 \mathrm{~L}$ port fuel injection turbocharged engine as the research object, based on the WLTC test cycle about the China $6 \mathrm{~b}$ emissions regulations, including some influence of several key technologies, such as fuel injector selection, intake VVT opening, fuel control and gear shift point matching, what can affect the particulate emissions from light-passenger vehicles. The results show that without particulate filter (GPF) technology, Using the original 4-hole fuel injector, the opened intake air VVT in catalyst light off, the optimized fuel control and gearbox shift point, the emission test results of the light-passenger vehicle can reach the development target of China $6 \mathrm{~b}$, what can avoid GPF blockage and regeneration problems in the market. Meanwhile, the cost of mass production and development cycle about vehicle is effectively reduced.
\end{abstract}

\section{Introduction}

With the continuous improvement of vehicle ownership and the increasingly serious environmental protection problems, the motor vehicle emission laws and regulations have become increasingly perfect and the emission limits have become increasingly strict. On December 23, 2016, the Ministry of environmental protection formulated stricter emission standards for light vehicles in phase 6 (national6) ${ }^{[1]}$, and stipulated that from July 1, 2023, all light vehicles sold and registered nationwide must meet the requirements of national $6 \mathrm{~B}$ standard. As shown in Table 1, compared with the national 5 standard, the national 6B standard requires less gas emissions, and increases the limit value of particle number PN, which puts forward higher technical requirements for existing supercharged engines and electronic control systems that only meet the national 5 emission level.

Table 1. Comparison of emission regulation limits between National 5 and National 6 .

\begin{tabular}{cccc}
\hline Emissions & National 5 & National $6 \mathrm{~b}$ & Change rate $(\%)$ \\
\hline $\mathrm{CO} / \mathrm{g} \cdot \mathrm{km}^{-1}$ & 1.0 & 0.5 & $-50.00 \%$ \\
$\mathrm{THC} / \mathrm{g} \cdot \mathrm{km}^{-1}$ & 0.10 & 0.05 & $-50.00 \%$ \\
$\mathrm{NMHC} / \mathrm{g} \cdot \mathrm{km}^{-1}$ & 0.068 & 0.035 & $-48.53 \%$
\end{tabular}

**Corresponding author: lisc@dfmc.com.cn 


$\begin{array}{cccc}\mathrm{NOx} / \mathrm{g} \cdot \mathrm{km}^{-1} & 0.060 & 0.035 & -41.67 \% \\ \mathrm{PM} / \mathrm{g} \cdot \mathrm{km}^{-1} & 0.0045 & 0.003 & -33.33 \% \\ \mathrm{PN} / \text { 个 } \cdot \mathrm{km}^{-1} & \text { 无要求 } & 6 \mathrm{E}+11 & -\end{array}$

In order to meet the national $6 \mathrm{~B}$ emission standard, some scholars and research institutions have carried out in-depth research on emission reduction, especially particulate matter emissions. Omar i.awad et al. ${ }^{[2]}$ summarized the automakers' approach to emissions regulation, and believed that GPF is an important means to reduce particulate emissions. Yoshitaka ITO et $\mathrm{al}^{[3]}$, through engine bench test and RDE test, found that GPF with high porosity could effectively minimize the PN emission at all engine operating points. Fang Tiegang et al. [4] summarized the mechanism of high particulate emissions from gasoline engines by studying the process of particulate emissions from gasoline engines, and the results showed that GPF was still an appropriate and cost-effective solution for particle emission considering fuel consumption and carbon dioxide increase. In conclusion, at present, the conventional technical means is to install GPF to achieve the target requirements of particulate matter emission. But GPF has the problems of exhaust aftertreatment, engine room design change, multiple durability verification and increased mass production cost, and for chassis type GPF, there existed carbon load prediction difficulty, increased regeneration fuel consumption and other problems, which bring great challenges to independent brand automobile manufacturers and EFI manufacturers.

For the emission control of vehicles without GPF, Xu Zheng et al [5], aiming at a 1.5L four cylinder gasoline engine with advanced energy saving and emission reduction technologies such as in cylinder direct injection, high-efficiency turbocharging, variable timing technology of intake and exhaust, integrated exhaust manifold, etc., improved the engine efficiency while maintaining the maximum torque of the engine through combustion system optimization and Miller cycle application. In addition, through the optimization of fuel injection beam and the application of $35 \mathrm{MPa}$ high-pressure fuel injection system, the engine emissions were greatly reduced to meet the requirements of GB $6 \mathrm{~B}$ particulate emission limit; Gao Yuanyuan [6] and others, aiming at a 1.5L supercharged cylinder direct injection gasoline engine, reduced the fuel consumption level of the whole vehicle and meet the national $6 \mathrm{~B}$ emission standard without GPF by adopting Miller cycle and combined with systematic friction reduction technology, split cooling and low-pressure exhaust gas recycling (EGR) technology. This study, for the first time, systematically proposes an optimization scheme to reduce particulate matter emissions and take gas emissions into account on a certain type of otto-cycle $1.5 \mathrm{~L}$ intake injection supercharged engine, so as to make a certain type of vehicle with this engine meet the national $6 \mathrm{~B}$ emission standard without GPF.

\section{Test object}

In this paper, an experimental study was carried out on a certain type of vehicle with $1.5 \mathrm{~L}$ port fuel injection turbocharged engine. The whole vehicle's mass was about $1,200 \mathrm{~kg}$, and the gearbox was a 6-gear double clutch gearbox. The engine was equipped with the intake VVT, the supercharging mode was exhaust gas turbocharging, and the aftertreatment was a national six formula three-way catalytic converter (without GPF). The specific parameters of the engine are shown in Table 2.

Table 2. Main engine parameters.

\begin{tabular}{cc}
\hline Name & Technical paramete \\
\hline Type & 4-cylinder, 4-Valve \\
Bore $/ \mathrm{mm}$ & 73 \\
Stroke $/ \mathrm{mm}$ & 87.2 \\
\hline
\end{tabular}




\begin{tabular}{cc}
\hline Firing order & $1-3-4-2$ \\
Compression ratio & 8.9 \\
Max torque(Nm) /engine speed(r/min) & $230 / 1800-4000$ \\
Connecting rod length(mm) & 147.12 \\
\hline
\end{tabular}

Based on the mechanism of particle production and the specific conditions of PN generation in WLTC cycle, this paper studies several measures to meet the requirements of national $6 \mathrm{~b}$ emission regulations without the use of GPF technology, such as injector selection, VVT opening, fuel control strategy, gearbox matching, etc. The engineering objectives of PM and PN emissions are set as $0.02 \mathrm{~g} / \mathrm{km}$ and $3 \mathrm{E}+11 / \mathrm{km}$ respectively, while taking into account that the gas emissions must achieve the emission development goals.

\section{Problem analysis}

The original emission of vehicle in WLTC cycle test was analyzed, and PN's emission result was $1.27 \mathrm{E}+12 / \mathrm{km}$, as shown in Figure 1 . The second sampling data showed that PN was mainly produced in the cold start, warm-up and cold engine acceleration stages in P1 phase, and in the heavy load and shift stages in P4 phase. The generation mechanism of particulate matter is as follows: in the cold start and warm-up stage of the vehicle, there are more fuel injection, uneven air mixing and serious fuel wet wall phenomenon, and the lower combustion efficiency of the cold engine will produce soot particles. The primary soot particles will agglomerate and absorb HC, metal ashes and sulfate to form accumulated particles (30-1000nm). During the combustion process of the engine, HC compounds and sulfate will form nuclear particles $(5-30 \mathrm{~nm})$ through Nucleation ${ }^{[7]}$. And under the transient conditions such as acceleration, deceleration and shifting, due to the dynamic effect of oil film and the transmission delay of various sensors, it is very difficult to control the parameters and air-fuel ratio of the engine, which could easily increase the control deviation of the transient air-fuel ratio, so as to worsen the emission of particles ${ }^{[8-9]}$.

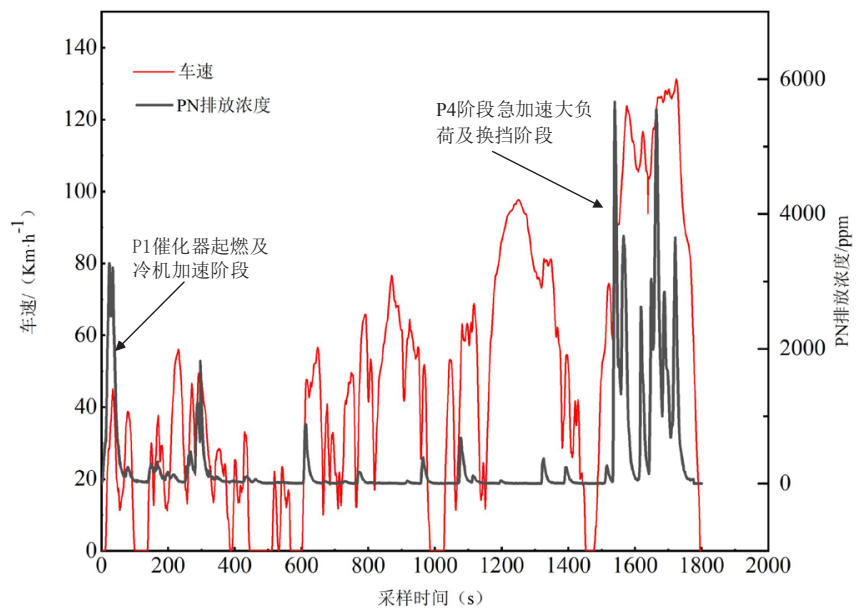

Fig. 1. The original PN emission of test vehicle in WLTC.

\section{Technical proposal}

In WLTC cycle test, the area with high PN emission was mainly related to fuel atomization and condition matching. Based on the existing powertrain (engine body, gearbox speed 
ratio, etc.), the technical route of enhancing fuel atomization and optimizing calibration was formulated, as shown in Table 3.

Table 3. Technical proposal of the study.

\begin{tabular}{|c|c|c|}
\hline Type & Original scheme & Scheme to be studied \\
\hline $\begin{array}{l}\text { Injector } \\
\text { selection }\end{array}$ & $\begin{array}{l}\text { 4-hole injector, 3.5bar injection } \\
\text { pressure }\end{array}$ & $\begin{array}{l}\text { 12-hole injector, 5bar injection pressure, } \\
\text { Reduce particle SMD and penetration } \\
\text { distance, Enhance atomization }\end{array}$ \\
\hline $\begin{array}{l}\text { Intake air } \\
\text { VVT open }\end{array}$ & $\begin{array}{l}\text { Open VVT at engine coolant } \\
\text { temperature of } 40{ }^{\circ} \mathrm{C}\end{array}$ & $\begin{array}{l}\text { Open intake air VVT in catalyst light-off } \\
\text { stage, Accelerate fuel atomization in start-up } \\
\text { and warm-up stage }\end{array}$ \\
\hline Fuel control & $\begin{array}{l}\text { More transient fuel } \\
\text { compensated when accelerating } \\
\text { or changing gear, Fuel } \\
\text { closed-loop and mid value } \\
\text { calibration in the lean direction }\end{array}$ & $\begin{array}{l}\text { Reduce or cancel transient fuel in some } \\
\text { engine point, fuel closed-loop control and air } \\
\text { fuel ratio to a little lean direction, Reduce } \\
\text { particulate matter caused by poor } \\
\text { atomization, balance NOx with enriching } \\
\text { air-fuel ratio after decelerating or fuel cut }\end{array}$ \\
\hline $\begin{array}{l}\text { Shift point } \\
\text { matching }\end{array}$ & $\begin{array}{l}\text { NEDC high speed condition, } \\
\text { Mainly considering fuel } \\
\text { consumption, Adopt economical } \\
\text { shift point }\end{array}$ & $\begin{array}{l}\text { WLTC P4 super high speed condition, } \\
\text { Reasonable matching of engine conditions, } \\
\text { Take into account the shift point of emissions }\end{array}$ \\
\hline
\end{tabular}

\section{Result}

Based on the comparison of PN emission results before and after improvement of each measure, the optimal scheme of fuel injector selection, intake VVT opening, fuel control optimization and shift point matching was selected, and the final improvement effect was verified.

\section{1 injector selection}

The number of injector holes and injection pressure have a great influence on fuel atomization, thus affecting particulate matter emission ${ }^{[10]}$. The original injector of the engine described in this paper is 4-hole injector with 3.5 bar injection pressure. The comparison scheme is 12 hole porous injector with 5 bar injection pressure. As shown in Figure 2, the SMD and penetration speed of 12 hole porous injector are better than that of 4-hole injector. When adopting the 12 hole injector, the air inlet is optimized to avoid fuel wet wall.

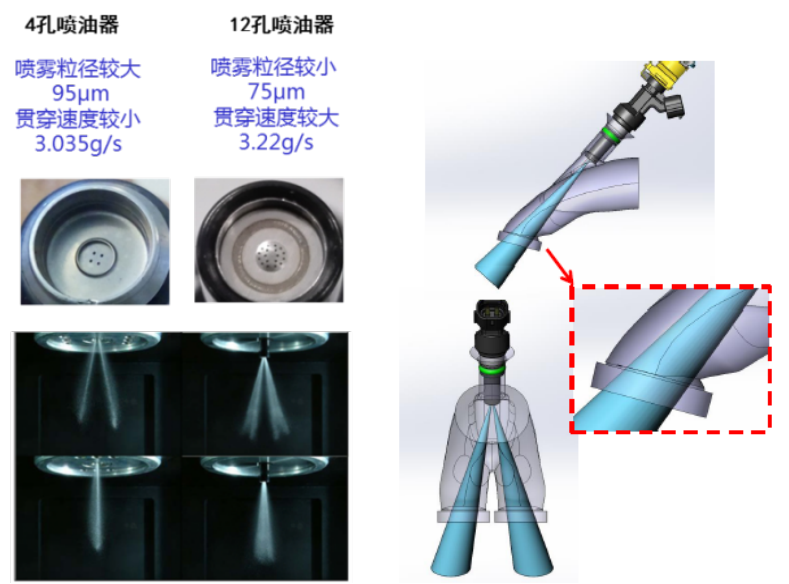


Fig. 2. Parameter comparison between 12 hole injector and 4 hole injector.

Comparing the PN emission of 4-hole injector and 12 hole injector by bench steady-state matching test, we found that under the steady-state condition of engine speed $1200 \mathrm{R} / \mathrm{min}$ and engine water temperature $40{ }^{\circ} \mathrm{C}$, the PN emission of 12 hole injector was significantly improved, and the improvement rate of each torque point was more than $40 \%$, as shown in Figure 3.

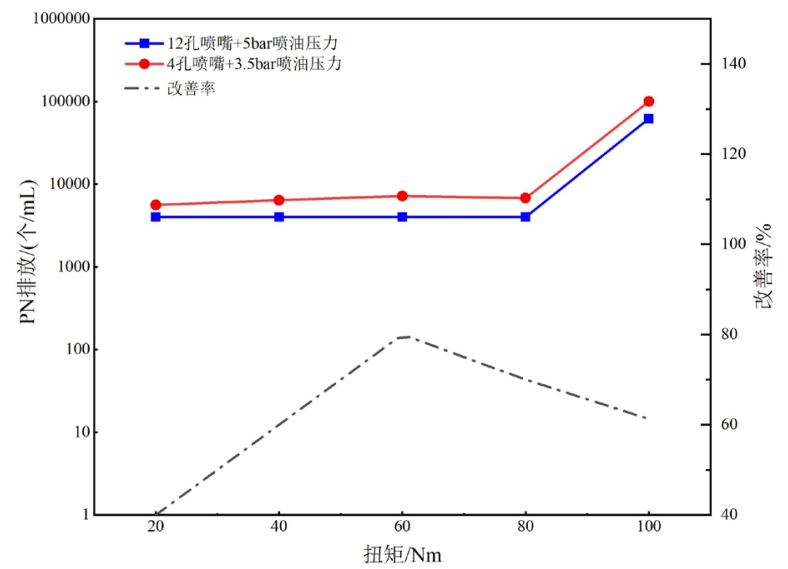

Fig. 3. PN emission of 12 hole injector and 4-hole injector in bench steady-state test.

The PN emission results of 4-hole injector and 12 hole injector by WLTC emission test cycle were shown in figure 4 . The results showed that the PN emission of 12 hole injector $(1.34 \mathrm{e}+12 / \mathrm{km})$ is higher than that of 4-hole injector $(1.27 \mathrm{e}+12 / \mathrm{km})$.

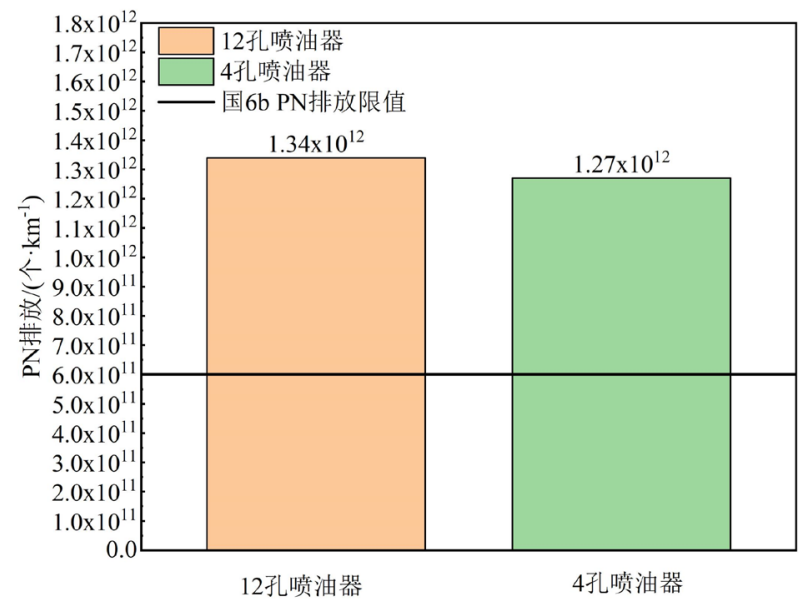

Fig. 4. PN emission of porous injector and 4-hole injector in WLTC cycle.

As shown in Figure 5, the PN emission concentration of WLTC cycle of 4-hole injector and 12-hole injector were compared. The PN emission concentration of 12-hole injector was higher than that of 4-hole injector in the transient acceleration and deceleration condition. This is because the particle size of 12-hole injector is smaller, which is conducive to fuel atomization in the steady-state condition of heat engine, but in the transient acceleration and deceleration condition, especially after the VVT open, waste gas will flow into the intake manifold to blow the smaller fuel particles, leading to poor transient fuel atomization and the increase of particulate emissions. Therefore, too small 
particle size does not necessarily improve PN emissions. Adaptation should be carried out according to specific engine models, and factors such as cost and inlet modification should be taken into account. Finally, the original 4-hole fuel injector was selected.

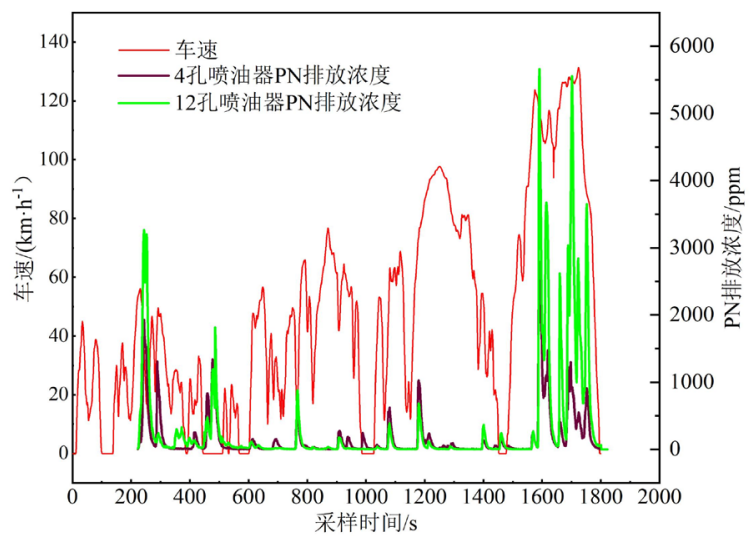

Fig. 4. PN emission of 12-hole injector and 4-hole injector in WLTC cycle.

\subsection{Open the intake VVT in light-off condition}

The existing scheme is to open the intake VVT when the engine coolant temperature up to $40{ }^{\circ} \mathrm{C}$, which fails to give full play to the advantages of VVT at cold start and catalyst light-off stage, while the single test of VVT parts can meet the requirements to open VVT at $-30{ }^{\circ} \mathrm{C}$ cold start. The improvement scheme in this study is to open VVT at the catalytic light-off stage, which can improve the temperature at the intake valve, the internal EGR rate, and the fuel atomization effect, but the driving performance should be taken into account as well.

In catalyst light-off condition, the intake VVT target phase and PID control are calibrated in detail to ensure the idling speed is stable and VVT control is accurate. The calibration control logic is shown in Figure 6.

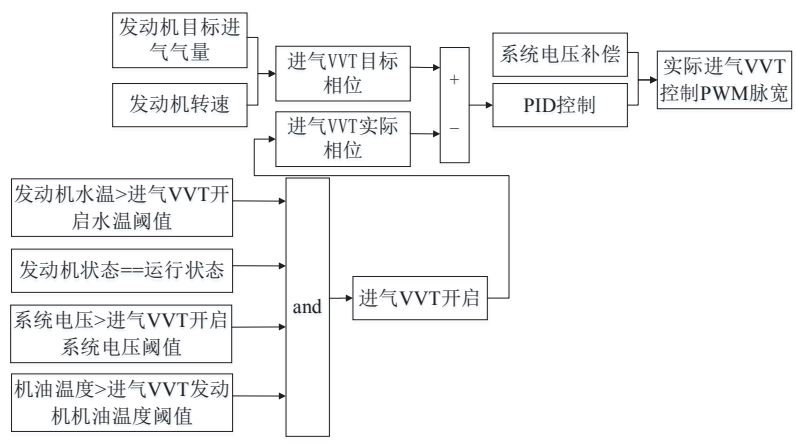

Fig. 6. Control logic of intake VVT calibration.

Finally, the VVT target phase in light-off stage was optimized to be $15^{\circ} \mathrm{CA}$. On the premise of controlling the target air-fuel ratio unchanged, the measured air-fuel ratio was increased by 2 , indicating that more fuel was involved in combustion and fuel atomization was better. So the target air-fuel ratio when VVT opened in catalyst light-off stage could be reduced by 2 to reduce the fuel injection. In the P1 phase of WLTC cycle, PN emissions in catalytic light-off stage were reduced, as shown in Figure 7. 


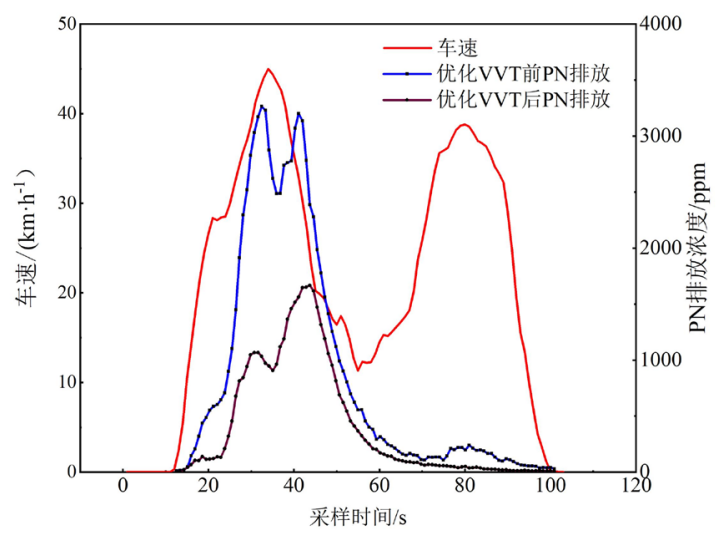

Fig. 7. PN emission concentration before and after VVT optimization.

\section{3 fuel control optimization}

In the P4 phase of WLTC cycle, the PM emission concentration increases rapidly under the transient acceleration condition, because at this time, the transient fuel is injected into the engine cylinder quickly, and there is not enough time to mix the transient fuel with fresh air, resulting in incomplete combustion of the mixture. According to the fuel control logic, the fuel target demand under transient acceleration condition was adjusted, as shown in Figure 8.

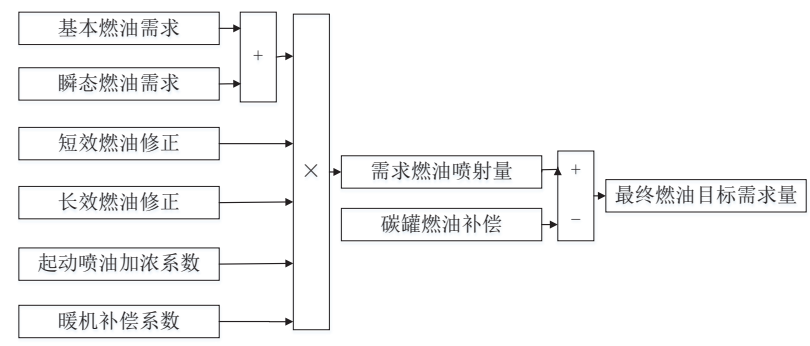

Fig. 8. Fuel control logic diagram.

the basic fuel demand is:

$$
\begin{aligned}
m_{\text {base }}= & \rho_{\text {actual }} \times V \times(F / A)_{\text {set }} \times \lambda_{\text {actual }} \\
& \times r_{\text {comp }}
\end{aligned}
$$

where $m_{\text {base }}$ is the basic fuel demand; $\rho_{\text {actual }}$ is the actual intake density; $V$ is the cylinder volume. $(F / A))_{\text {set }}$ is the fuel air ratio setting point determined according to the basic fuel air ratio, obtained through fuel detection; $\lambda_{\text {actual }}$ is the target equivalence ratio, obtained according to the engine operation condition calibration; $r_{\text {comp }}$ is the fuel compensation coefficient, which is used to correct the fuel supply inhomogeneity of each cylinder caused by the manufacturing error of cylinder volume.

Transient fuel oil is:

$$
m_{\text {trans }}=m_{\text {amplitude }} \times r_{\text {filter }}
$$


where $m_{\text {trans }}$ is the transient fuel demand, $m_{\text {amplitude }}$ is the transient fuel demand, $r_{\text {filter }}$ is the second-order low-pass filter coefficient.

By decreasing transient fuel demand amplitude to reduce the transient fuel demand in acceleration stage, and optimizing the target equivalence ratio in basic fuel demand, the air-fuel ratio of the mixture is optimized to increase in order to reduce the PN emission concentration. In order to balance the increase of $\mathrm{NO}_{\mathrm{x}}$ emission caused by the increase of air-fuel ratio, the method is to lower the air fuel ratio a little after decelerate or fuel-cut point. According to the characteristics of gradually increasing temperature of intake valve in WLTC cycle, temperature correction is used to increase the warm-up compensation coefficient in the high $\mathrm{NO}_{\mathrm{x}}$ area. After optimization, the PN emission concentration is effectively reduced under the acceleration condition in WLTC cycle P4 stage, as shown in figure9.

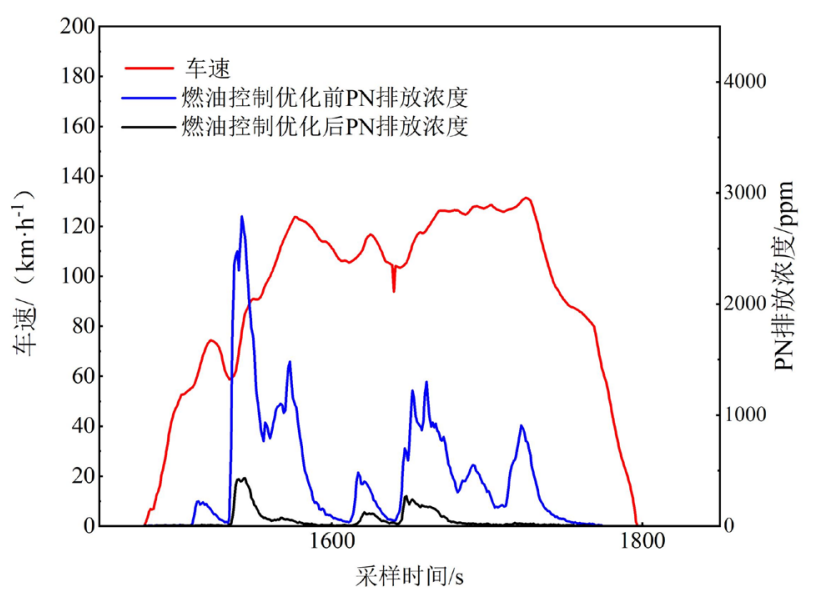

Fig. 9. Effect of fuel control on PN emission concentration.

\subsection{Transmission shift point optimization}

In this study, the shift point in the second rapid acceleration stage (speed from $59 \mathrm{~km} / \mathrm{h}$ to $89 \mathrm{~km} / \mathrm{h}$ ) of P4 stage was optimized. Before the rapid acceleration, the gear was reduced from 6th gear to 4th gear, so that the engine's low-speed full load condition was adjusted to the high-speed small load condition. And exhaust turbine supercharging pressure was reduced from $200 \mathrm{KPa}$ to $170 \mathrm{kpa}$ to reduce the actual intake density, so that the fuel demand for large load was effectively reduced. The PN emission concentration before and after the optimization of shift point were shown in Figure 10. 


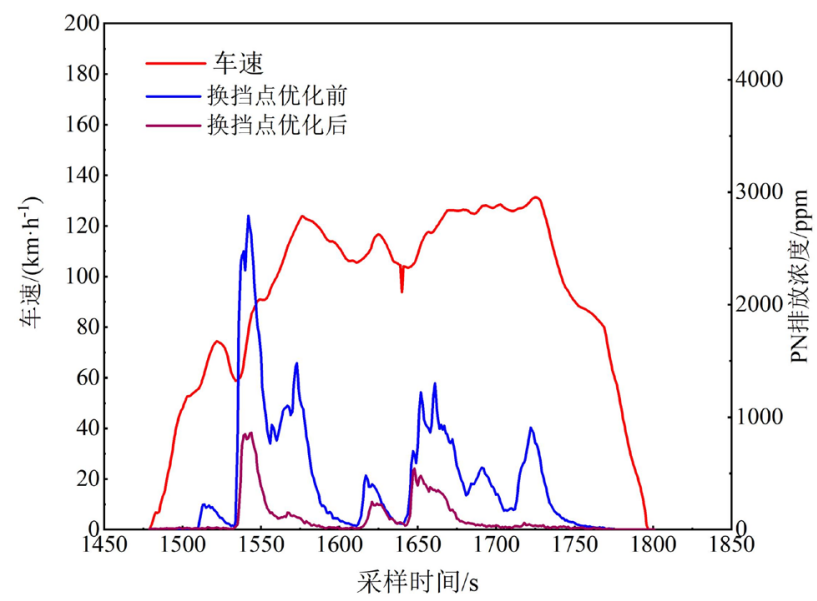

Fig. 10. Effect of shift point on particulate matter emission.

\subsection{Comprehensive validation}

After the comprehensive implementation of various measures, the PN emission of each phase of WLTC cycle has been improved significantly, and the number of particulate emissions per kilometer in each stage of P1, P2, P3 and P4 was reduced. Compared with that before optimization, the PN emissions of each WLTC cycle stage after optimization were reduced by $29.70 \%, 33.33 \%, 66.67 \%$ and $84.38 \%$ respectively, as shown in Figure 11.

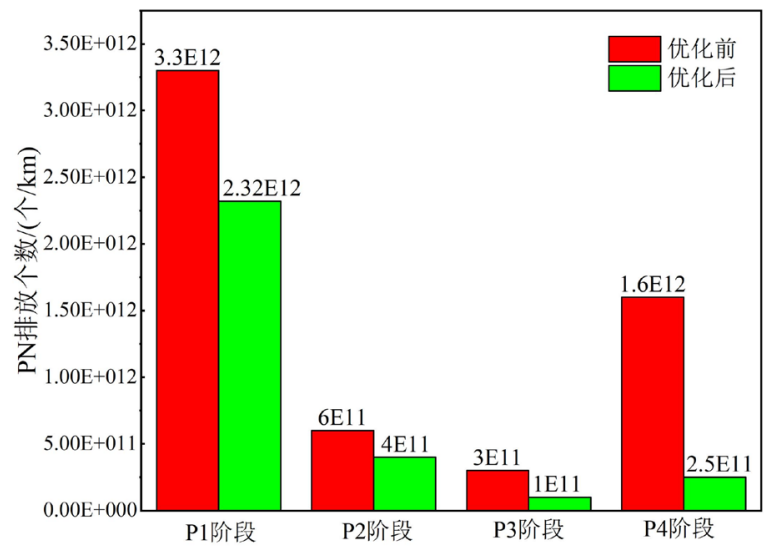

Figure 11. PN emission in each stages of WLTC cycle before and after optimization.

As shown in Figure 12, after optimization, the number of particles in WLTC cycle was reduced from $12.7 \mathrm{e}+11 / \mathrm{km}$ to $2.52 \mathrm{e}+11 / \mathrm{km}$, with the reduction rate of $80.16 \%$. The mass of particles was reduced from $0.002 \mathrm{~g} / \mathrm{km}$ to $0.00068 \mathrm{~g} / \mathrm{km}$, with the reduction rate of $66.00 \%$. It indicated that opening intake air VVT in catalyst light off, fuel control and gear shift matching optimization could significantly improve the particulate emission, and the particulate emission could meet the requirements of the project target without GPF. 

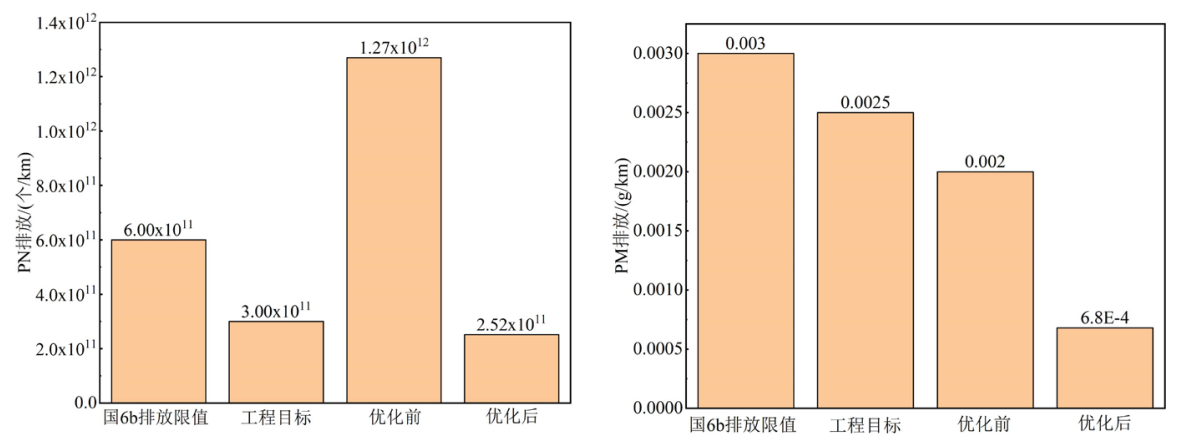

Fig. 12. Particle emission results before and after optimization.

Figure 13 shows the results of $\mathrm{THC}, \mathrm{Co}, \mathrm{NO}_{\mathrm{x}}, \mathrm{NMHC}$ and other gas emissions after optimization, which is smaller than the national $6 \mathrm{~B}$ project goal, and can meet the requirements of national $6 \mathrm{~B}$ emission regulations without GPF. Compared with the GPF scheme, the development cost and development cycle of the vehicle are reduced because of the cancellation of GPF temperature and differential pressure sensor and its pipeline, GPF carrier.

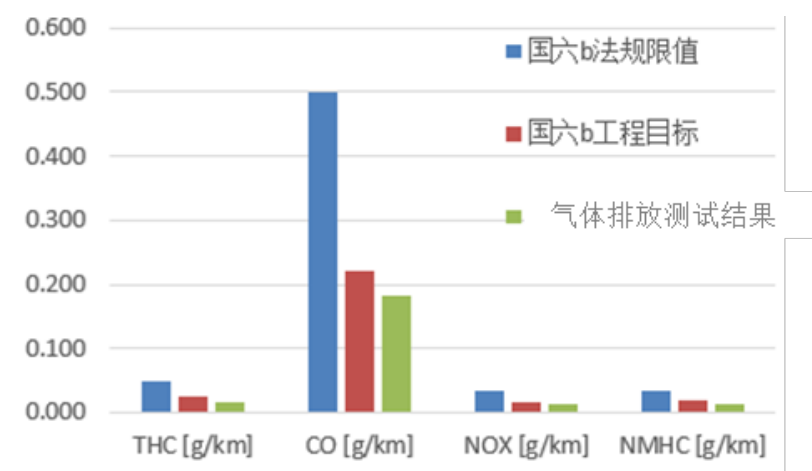

Fig. 13. Optimization results of gas emissions after particulate matter improvement (GPF cancellation).

\section{Conclusion}

In this study, several key technologies, such as injector selection, the opened intake air VVT in catalyst light off, fuel control optimization and shift point matching, were studied for port fuel injection turbocharged gasoline engine without the use of GPF technology. It meets the requirements of national $6 \mathrm{~B}$ emission regulations, reduces the development cost and development cycle of the whole vehicle, and improves the market competitiveness of vehicle models. The measures in this paper can be applied to the vehicle with direct injection engine except for the injector used for airway injection. In conclusion, the contents of this study are as follows:

(1)Under stable operating conditions of $1200 \mathrm{r} / \mathrm{min}$ and engine water temperature of $40^{\circ} \mathrm{C}$, PN emission of 12-hole injector was significantly improved, and the improvement rate of each torque point was more than $40 \%$. The PN emission in WLTC cycle of 12 hole injector is higher than that of 4 Hole Injector, because the PN emission concentration of 12 hole injector is higher than that of 4 Hole Injector in the transient acceleration and deceleration condition. 
(2)Opening intake VVT in catalyst light-off stage can effectively improve the fuel atomization characteristics of cold start, and the target phase of VVT in the light-off stage is finally determined as $15^{\circ} \mathrm{CA}$. on the premise of controling target air-fuel ratio unchanged, the measured air-fuel ratio is increased by 2 , indicating that more fuel was involved in combustion and fuel atomization was better. So the target air-fuel ratio when VVT opened at catalyst light-off stage could be reduced by 2 to reduce the fuel injection, and then reduce the emissions.

(3) By decreasing transient fuel demand amplitude to reduce the transient fuel demand in acceleration stage, and optimizing the target equivalence ratio in basic fuel demand, the air-fuel ratio of the mixture is optimized to increase in order to reduce the PN emission concentration. In order to balance the increase of $\mathrm{NO}_{\mathrm{x}}$ emission caused by the increase of air-fuel ratio, the method is to lower the air fuel ratio a little after decelerate or fuel-cut point, what can cause $\mathrm{NO}_{\mathrm{x}}$ emission meets the development requirements of national $6 \mathrm{~B}$ emission regulations.

(4)The shift point of the gearbox is optimized to avoid the heavy load area of the engine operating point, which is conducive to improving the particle impulse in P4 stage

In the follow-up work, the increase of the curb weight will lead to the increase of the sliding resistance at the same time, which will eventually cause the increase of the engine load or the change of the shift point. In addition, for MT gearbox models, the load changes greatly during the shift acceleration, which will lead to the increase of the particulate matter, so it is necessary to carry out comprehensive calibration and matching in combination with the measures in this paper.

\section{References}

1. 中华人民共和国环境保护部. 轻型汽车污染物排放限制及测量方法(中国第六 阶段) : GB 18352.6-2016[S]. 北京: 中国环境出版社, 2017.

2. Omar I.Awad,Xiao Ma,Mohammed Kamil, et al. Particulate emissions from gasoline direct injection engines: A review of how current emission regulations are being met by automobile manufacturers. Science of the Total Environment, 718(2020):1-15.

3. Yoshitaka Ito, Takehide Shimoda, Takashi Aoki, et al. Next Generation of Ceramic Wall Flow Gasoline Particulate Filter with Integrated Three Way Catalyst[C]. SAE Technical Paper.2015-01-1073, 2015.

4. 方铁刚, 王利兵, 王志. 汽油直喷发动机的颗粒物排放研究综述 $[\mathrm{J}]$. 汽车安全 与节能学报, 2017,8(3):226-238.

5. 徐政, 龚伟国, Scholten I, 等.车用 $1.5 \mathrm{~L}$ 浴轮增压直喷汽油发动机开发 $[\mathrm{J}]$. 汽车 安全与节能学报, 2018,9(3):339-357.

6. 高媛媛, 吴坚, 孙凡嘉, 等. 新一代高效低排放增压缸内直喷汽油机开发 [J]. 现代车用动力, 2019(2): 6-12.

7. 帅金石, 董哲林, 郑荣, 等. 车用汽油机颗粒物生成机理及排放特性研究进展 [J]. 内燃机学报, 2016, 34(2) : 105-116.

8. 李岳林, 龚宏义, 徐东辉, 等. 汽油机瞬态空燃比控制器参数优化控制策略研 究 $[\mathrm{J}]$. 汽车技术, 2016,000(005) : 31-36.

9. 逯家鹏, 李幼德, 吕景华, 等 $[\mathrm{J}]$. 自动挡车辆冷起动降排放换挡控制策略. 吉 林大学学报(工学版), 2016,46(2) : 348-353. 
10. Ziyoung Lee, Taehoon Kim, Sungwook Park,et al. Review on spray, combustion, and emission characteristics of recent developed direct-injection spark ignition (DISI) engine system with multihole type injector[J]. Fuel, 259(2020):1-34. 